\title{
4. EXERCISES FOR PIANO AND THEIR ROLE IN THE PEDAGOGICAL ACTIVITY OF VITALII SECHKIN
}

\section{Inna Hatipova ${ }^{5}$}

\begin{abstract}
In the article, the author analyses the role of technical exercises used in his pedagogical activity by Vitaly Sechkin, remarkable pianist and professor, Honoured Artist of Ukraine. He paid particular attention to the development of the technical skills of his students, for which he used various exercises and virtuoso etudes. A detailed characteristic is made of the particularities of C.-L. Hanon's and J. Brahms's sets of exercises, which pursue similar objectives - the development of finger speed, the freedom to execute different kinds of texture, assimilation of tonalities. The professor's favourite exercises and his methodical recommendations are mentioned as well.
\end{abstract}

Key words: piano, piano technique, exercise, Charles-Louis Hanon, Johannes Brahms

\section{Introduction}

The professional training program for pianists includes multiple creations whose interpretation requires a certain level of technical mastery. For this reason, in order to develop the necessary skills, there is a system of exercises in piano pedagogy that offers the possibility to overcome any technical difficulty. Moreover, the exercise, as one of the main practical means in acquiring technical skills, has always been of great interest to music teachers and to theorists and practitioners alike. In this context, the pianist and teacher A. Jilina relates, "The significance of the place and role of exercises in the piano teaching system is accentuated by their contribution to the development of special cycles focused on training the technical mastery of outstanding musicians, beginning from the $17^{\text {th }}$ century and to the present day." 6

Each collection of exercises encompasses the achievements of different piano schools from different historical epochs and represents, at the same time, an attempt to systematize the forms of piano technique. J.S. Bach called his Two- and Three-Part Inventions (in two and three voices) "exercises for the development of polyphonic playing, of a true legato". Collections of piano exercises were written by G. Diruta, F. Couperin, M. Clementi, C. Czerny, K. Tausig, J. Brahms, F. Busoni, M. Long, J. Gat, E.-R. Blanchet, F. Liszt and others. The collections of technical exercises of some contemporary masters are a particularly valuable practical material, such as Daily pianistic exercises by E. Timakin, Daily pianistic exercises by I. Ryabov, Piano technique by I. Štěpánová-Kurzová.

\section{Discussions}

The importance of developing technical qualities is indisputable, which is confirmed by N. Frolova: "The problem of pianistic abilities and skills is a decisive and particularly important one in the process of complex training of the

\footnotetext{
${ }^{5}$ Professor PhD., Academy of Music, Theater and Fine Arts from Chișinău, Republic of Moldavia, email: hatipovainna@yahoo.com

${ }^{6}$ Jilina (2001), pp. 4-5
} 
student-musician, be he a future music teacher in a general school, a piano teacher or concert artist. It is difficult to disagree with the great German pianist Hans von Bülow who said, 'The pianist needs three qualities: firstly, technique; secondly, technique; thirdly, technique.' Namely, the technical freedom is a primordial condition for unchaining musical expressiveness." 7

The leading figures of piano art addressed the issue of technical exercises and used them in their practice, a fact that speaks of their primary role both in daily practice and in pedagogical activity as a particularly effective method in the development of piano technique. The same principle was followed and promoted in pedagogical practice by the pianist, teacher, composer, Honored Artist of Ukraine Vitaly Sechkin ${ }^{8}$ who worked at the State Conservatory of Moldova in the period between 1984 and 1988. Despite the fact that he carried out his activity within the higher institution of artistic education of Moldova only for four years and, frankly, he had not even managed to form his own class, Vitaly Sechkin is remembered as a remarkable teacher, brilliant performer and exceptional organizer. The author of this paper had the special opportunity to study the art of piano performance for three years under the guidance of this wonderful teacher (until the tragic moment of his passing away on May 3, 1988).

V. Sechkin worked a lot with his students, forgetting about holidays, weekends or vacations. Most often, the notion of time completely lost its meaning when the student (came to his class with) brought to the lesson well-prepared material in terms of both quantity and quality. The teacher let himself be carried away by inspiration and passion in the meticulous decipherment of the musical text to reveal the interpretative aspects with the greatest precision, so the lesson could last for several hours. In choosing the program for his students, Vitaly Sechkin opted for creations from his own concert repertoire. These include the following works: Partita $c$-moll by J.S. Bach, sonatas No. 3, 7, 8, 12, 14, 23 by L. van Beethoven, etudes No. 1, 2, 3, 4, 12, 14, 18, 22, 23, 24, Andante spianato et Grande Polonaise brillante op. 22 by F. Chopin, the Transcendental Études by F. Liszt, Prelude, choral and fugue by C. Franck, Prelude and fugue $d$-moll by A. Glazunov, Sonata No. 7 by S. Prokofiev, piano concertos by L. van Beethoven, E. Grieg, P.I. Tchaikovsky and many others.

One of the basic principles of the teacher was the education of independent work skills. Often, talking about the content of ideas of the piece, about various details of interpretation, "sound color", the master explained what should be done,

\footnotetext{
${ }^{7}$ Frolova (2008), p. 319

${ }^{8}$ V. Sechkin was born on September 5, 1924 in the city of Kharkov, Ukraine. He graduated from the Special Boarding High School of Music in Kharkov. After graduating from the Kharkov Conservatory at the Piano Department in the class of Professor N.B. Landesman (1947) and at the Composition Department in the class of Professor M.D. Tits (1950), Vitaly Sechkin, in order to complete his interpretative mastery, pursued his postgraduate studies at the P.I. Tchaikovsky State Conservatory in Kiev under the auspices of Professor K.N. Mikhailov. Subsequently, he continued the formation of his artistic personality within the P.I. Tchaikovsky State Conservatory in Moscow in the class of the famous professor I.I. Zak. In 1957, Vitaly Sechkin settled in Kiev and began his pedagogical activity at the P.I. Tchaikovsky State Conservatory. In 1976, he was awarded the title of Professor and, until 1983, he acted as dean of the Piano Faculty of this institution. Among his graduates are People's Artist of Ukraine, professor of P.I. Tchaikovsky National Music Academy of Ukraine Liudmila Martsevich; People's Artist of Ukraine, soloist of the National Philharmonic of Ukraine Evgeniya Basalaeva; soloist of the National Philharmonic of Ukraine Natalia Nalizco; the winner of numerous international competitions Mikhail Shramko. In 1984, Vitaly Sechkin accepted the invitation to hold the position of head of the Special Piano Department of G. Musicescu State Conservatory from Moldova.
} 
played the work on the piano, but left it to the student to find the ways how to achieve the intended purpose. Such an approach to the task encouraged the student to get involved and actively participate in treating the content of the musical creation, thus stimulating the search for their own ways of expressing the compositional idea and shaping individual perceptions through the characteristics of each personality. Besides this, the teacher did not cease to repeat that independent work educates a responsible attitude to the work done, forges character and improves interpretative stamina.

Having a brilliant technical training, Vitaly Sechkin reserved a special place in the teaching process for the development of the piano apparatus because he believed that continuous work on perfecting technical skills was an indispensable factor in achieving professionalism by a pianist-performer. This is the reason why, probably, V. Sechkin's class was the only one in the entire conservatory where scales, arpeggios and various exercises resounded. If in the hall you heard someone playing exercises from C.-L. Hanon's or J. Brahms' collections, you could be sure that this someone was a disciple of Vitaly Sechkin.

V. Sechkin drew the attention of students to the fact that C.-L. Hanon, in the preface to his collection, proposed that the exercises should be studied with a metronome: "[...] to start in tempo 60 and to reach gradually tempo 108." The teacher also said that during the practice it is extremely important to raise the fingers very well, to play each note "separately" and to respect strictly the synchronicity of the hands. The quality of the sound emission is essential as well: when the exercises have been well assimilated, it is recommended to add accents, thus making the transition from a mechanical interpretation to an expressive one. In addition, it is useful to add wrist movements, which bring the practice of exercises closer to the interpretation of different piano opuses.

From this collection, Vitaly Sechkin used the following exercises directly: No. 2 , No. 21 , No. 22 , No. 31 , No. 46 , No. 50 , No. 54 , No. 57 , No. 58 , No. 59 , No. 60. This set of exercises has been selected in such a way that each number is oriented towards a certain type of technique distinct from the others, for example: five consecutive fingers, hand rotation, trills, thirds, octaves, etc.

Another collection of exercises that V. Sechkin recommended to his students is 51 Exercises for Piano by the distinguished German composer and pianist Johannes Brahms. The exercises were composed during the artistic maturity of the composer (1890-1893) and, together with the famous cycles of piano pieces op. 116, 117, 118, 119, represent the quintessence of the Brahms' piano style. The exercises were first published in 1893 by Fritz Zimrock under the title 51 Übungen für Pianoforte. The collection did not receive an opus and was divided into two notebooks: exercises from 1 to 25 constituted the first notebook, from 26 to 51 - the second. It is worth noting that all the footnotes in the musical text belong to the author, and now we can only regret that they are short and few in number.

"During the analysis of the groups of exercises, it is observed that the variants of exercises for such types of technique as tremolo, trills and scales are excluded - unfortunately, these modes are not included in the collection. Instead, it

\footnotetext{
${ }^{9}$ Hanon (2002), p. 3
} 
can be seen that the polyrhythmic and polyphonic technique, the technique of double notes and large stretches predominate, new modes are introduced: broken octaves in the structure of arpeggios and wide broken intervals." 10

From this collection, the teacher mainly used exercises No. 30 and No. 32 a, b. Being convinced of the effects that these exercises have in training and warming the hands to the actual study of the musical creations, but also in strengthening the muscles of the palm, the author of the present article has also included some exercises in her educational and interpretative activities, which are grouped into two sets:

1. No. 2 a, No. 4 , No. 28 , No. 29 , No. 34 a, No. 36 , No. 47 , No. 48 ;

2. No. 7 , No. 8 a, b, No. 15 , No. 17 , No. 20 , No. 24 b, No. 26 a, c, No. 30 , No. 33a, No. 39 , No. 40a, No. 41 b.

V. Sechkin was of the opinion that the teacher should not only choose for the student a set of exercises, but also regularly monitor the quality of their execution. The tempo, rhythm, dynamics, the sound quality require permanent checking and correction. In choosing exercises he, also, took into consideration the student's individual particularities as well as his level of preparation at the current stage, developing specially those technical elements that were less discussed before.

\section{Results}

One can talk about the inutility of working on exercises only when they are played mechanically, in large quantities, without assessing our own shortcomings or technical possibilities. At the same time, the exercises should not be treated as a miracle key in the issue of technical perfection; undoubtedly, they should be completed with the study of scales, virtuosity pieces and etudes. However, it is well known that:

- technical exercises are a wonderful tool for warming up the hands;

- certain technical elements are developed much more efficiently through exercises than directly through the practice of concert pieces;

- the exercises contribute to the development of technical resistance and ensure the rationalization of work;

- the exercises not only develop the piano technique, but also keep it constant at a proper level.

V. Sechkin always emphasized that the results will be evident when the student takes into account two essential aspects: the method of work and the organization of the study routine. The method of playing the exercises includes the following:

- their diversity (forms and elements of piano texture);

- self-control over all hand movements and sensations while playing;

- controlling piano tone quality and changing, if necessary, the way the sound is emitted.

The study routine is also of great importance. Firstly, the exercises should be played every day, but not more than for an hour. Secondly, an alternation of 
different types of exercises is necessary, accompanied by a permanent control of the state of the pianistic apparatus, without allowing its overload. Finally, it is beneficial to change the order of the exercises periodically to avoid distracting attention while playing.

\section{Conclusions}

V. Sechkin's pedagogical practice, the choice of exercises was made with great care and thinking: depending on the purpose pursued, the teacher either used the collections of exercises of the above-mentioned authors or invented his own examples. However, he repeatedly said, "The result of studying the exercises will be obtained only when the pianist, once he has already mastered them, can apply them as means of expressiveness." 11

V. Sechkin was convinced that exercises are the most effective way of developing piano technique, because they concentrate in themselves many complicated technical formulas and offer the student the possibility to study them in an optimal pace. Taking into account the individual traits and interests of his disciples, V. Sechkin selected exercises for each student separately because he held the opinion that an exercise the student likes is much more beneficial and useful, and the desired result will be achieved in a shorter period of time. Thus, the teacher skillfully merged the objective factors in the development of piano technique with the subjective ones and, thus, managed to accelerate the study process.

\section{References}

1. Frolova, N. (2008). Puti sovershenstvovaniya fortepianno-ispolnitel'skoj podgotovki budushchego pedagoga-muzykanta [Ways of improving piano playing training of a future music teacher]. Izvestiya Samarskogo nauchnogo centra Rossijskoj akademii nauk. Pedagogika i psihologiya, Filologiya i iskusstvovedenie, 2008(1), 319-325.

2. Hanon, C.-L. (2002). Pianist-virtuoz. 60 uprazhnenij dlya dostizheniya beglosti, nezavisimosti, sily i ravnomernogo razvitiya pal'cev, a takzhe legkogo zapyast'ya [Pianist-virtuoso. 60 exercises to achieve fluency, independence, force and equal training of the fingers together with the light wrist]. Saint Petersburg: Kompozitor.

3. Jilina, A. (2001). Uprazhnenie v teorii i praktike obucheniya muzyke (na materiale trudov zapadnoevropejskih pedagogov-muzykantov i metodistov) [The exercise in the theory and practice of teaching music (on the basis of the works by Western European music teachers and educators)] [PhD thesis, Moscow Pedagogical State University].

Disser Cat. https://www.dissercat.com/content/uprazhnenie-v-teorii-i-praktikeobucheniya-muzyke-na-materiale-trudov-zapadnoevropeiskikh-pe

4. Milstein, Ya. (1983). K voprosu o fortepiannyh uprazhneniyah [On the issue of piano exercises]. In Ya. Milstein. Voprosy teorii $i$ istorii ispolnitel'stva [Issues in the theory and history of music performance]. Moscow: Sovetskij kompozitor.

5. Suhova, L., \& Sadritdinova, M. (2017). Iogannes Brams. 51 uprazhnenie dlya fortepiano [Johannes Brahms. 51 exercises for piano] [Paper presentation]. 10 $0^{\text {th }}$ International Online Scientific Conference (October 17 - November 17, 2017) within the international festival The Days of Germany in Tambov 2017, Tambov, Russia. https://rachmaninov.ru/assets/uploads/konf/dgt_2017/suxova-1.g.-sadritdinova-m.m.pdf

\footnotetext{
${ }^{11}$ Milstein (1983), p. 254
} 